\title{
KNOCKING ON AMERICA'S DOOR. BASQUE FOREIGN POLITICS IN THE US DURING THE SPANISH CIVIL WAR AND THE SECOND WORLD WAR
}

\author{
LLAMANDO A LA PUERTA DE AMÉRICA. LA POLÍTICA EXTERIOR \\ DEL GOBIERNO VASCO EN EL EXILIO DURANTE LA GUERRA CIVIL \\ ESPAÑOLA Y LA SEGUNDA GUERRA MUNDIAL (1936-1945)
}

David Mota Zurdo*

$\mathrm{PhD}$ Modern History

Isabel I University, Burgos, Spain

\begin{abstract}
This article analyzes the so-called Atlanticist strategy and how was put into practice by the Basque government-in-exile trough two major periods: on the one hand, the Basque government delegation's activities in New York during the Spanish Civil War; it seeks to understand its origin, composition, behavior and relationship with American institutions-such as the National Catholic Welfare Conference and the State Department and its different agencies. On the other hand, it studies Basque lobbying activities during the Second World War. This was a key period since, as it will be shown in the forthcoming pages, during those years there was an effective collaboration between Basque institutions and certain pivotal American agencies, namely, the Coordinator of Inter-American Affairs, the Office of Coordinator of Information, the Office of Strategic Services and the Federal Bureau of Investigation.
\end{abstract}

KEYWORDS: Basque Government in-exile; USA; Spanish Civil War; World War II; Spying.

RESUMEN: Este artículo analiza la denominada estrategia atlantista y cómo fue puesta en práctica por el Gobierno Vasco en el exilio a través de dos grandes etapas: por un lado, las actividades de la delegación del Gobierno Vasco en Nueva York durante la Guerra Civil española, atendiendo a su origen, composición, actuación y relación con instituciones norteamericanas como la National Catholic Welfare Conference (NCWC), el Departamento de Estado y sus diferentes agencias. $Y$, por otro, se estudian las labores de lobbying vascas durante la Segunda Guerra Mundial. Un periodo clave, pues, como se verá en las siguientes páginas, durante aquellos años se produjo una colaboración efectiva entre las instituciones vascas y las agencias estadounidenses de la Coordinator of Inter-American Affairs (CIAA), la Office of Coordinator of Information (COI), la Office of Strategic Services (OSS) y el Federal Bureau of Investigation (FBI).

PALABRAS CLAVE: Gobierno Vasco en el exilio; Estados Unidos; Guerra Civil; Segunda Guerra Mundial; Espionaje.

* Correspondence to: David Mota Zurdo, Facultad de Humanidades y CCSS, Departamento de Historia y Geografía, calle de Fernán González, 76, 09003 Burgos (Spain) - davidmotazurdo@gmail.com - http://orcid.org/0000-0002-9578-8069

How to cite: Mota Zurdo, David (2020). "Knocking on America's door. Basque Foreign Politics in the US during the Spanish Civil War and the Second World War (1936-1945)»; Historia Contemporánea, 64, 983-1010. (https://doi.org/10.1387) hc.20374).

Received: 10 November, 2018; Accepted: 25 January, 2019.

ISSN 1130-2402 - eISSN 2340-0277 / (C) 2020 UPV/EHU 


\section{Introduction}

This article will reconstruct the process through which the Atlanticist strategy was elaborated and put into practice by the Basque government during exile; in other words, how the latter sought a preferential relationship with the US government as a way of recovering its sovereignty over Basque territory. To this end, it gave special protagonism to the institutions of representation of the Basque executive power in foreign countries with capacity of political interlocution, that is, its delegations.

Thus, this article analyzes two major periods: on the one hand, the Basque government delegation's activities in New York during the Spanish Civil War (hereon SCW); it seeks to understand its origin, composition, behavior and relationship with American institutions-such as the National Catholic Welfare Conference (NCWC) and the State Department and its different agencies. On the other hand, it studies Basque lobbying activities during the Second World War (WW2). This was a key period since, as it will be shown in the forthcoming pages, during those years there was an effective collaboration between Basque institutions and certain pivotal American agencies, namely, the Coordinator of Inter-American Affairs (CIAA), the Office of Coordinator of Information (COI), the Office of Strategic Services (OSS) and the Federal Bureau of Investigation (FBI).

Moreover, this article analyzes how Basque political leaders decided to get involved in WW2, choosing USA as its fundamental ally to reinstate democracy over Basque territory. Finally, it also examines the rapprochement between Basques and American Catholicism, and the pro-allies activities - both of propaganda and espionage - carried out by the Basque Intelligence Service (hereon, BIS) in America (a collaboration whose main purpose was that United States intervened in Spain to depose Franco and reestablish democracy).

\section{The Basque Lobbying activities during the SCW: between the NCWC and the US Department of State}

Several months after the outbreak of the SCW, in October 1936, and an ensuing long statutory process initiated during the II Republic, the first 
Autonomous Basque Government was created ${ }^{1}$. Until Franco's army took control of Bilbao, in June 1937, their main political priority was, logically, focused on military issues, although foreign affairs were also considered important ${ }^{2}$. Hence, from October 1936 to June 1937, the Basque government created several institutions for para-diplomatic representation in Europe and America, the so-called delegations, which remained active during almost all the period in exile ${ }^{3}$. One of the most emblematic delegations was located in New York. This was created by Antón Irala and Manuel and Ramón de la Sota in 1938-a particularly difficult period for those who remained loyal to the Spanish Republic and were trying to obtain the support of the American giant.

At the end of that year, America was still suffering the consequences of the Wall Street Crash of 1929, with very high unemployment rates combined with increasing social and labor tensions ${ }^{4}$. On the other hand, Spain was suffering from a fratricidal war which confronted a republican side - increasingly more fractured - against an insurgent side-increasingly closer to victory. The Spanish war could determine the future of democracy; that was how part of the American society interpreted it, which is why they supported the republican government. However, not everybody saw it this way. A significant sector of American society, influenced by the pro-Franco propaganda of the Hearst Corporation, believed the Spanish conflict was instead a fight against communism, atheism and impiety, therefore it was the duty of America not to intervene in favor of a republican government which would eventually help the Bolshevik expansion in Europe ${ }^{5}$.

Such polarization of opinions put president Franklin D. Roosevelt in a dilemma: either support the removal of the weapons embargo his government had imposed on Spain in 1936, losing the so-needed Catholic vote; or be harshly criticized by those who considered this move as unjust and beneficial for the insurgents ${ }^{6}$. Roosevelt had to decide between lifting the embargo and jeopardizing neutrality, making relations more difficult, on the one hand, with Berlin and Rome and, on the other, with London, Paris

1 Granja, 2003, p. 224; Núñez, 2006, p. 357.

2 Ugalde, 1996.

3 Álvarez and Sanz, 2011, pp. 2-4.

4 Jenkins, 2002, p. 283.

5 DeConde and Burns, 2001.

6 Bosch, 2012, pp. 181-216; Thòmas, 2007, pp. 38-56. 
and the isolationist sectors of his government, who favored non-intervention, or be pragmatic and opt for a different type of behavior ${ }^{7}$. Evidently, he chose the latter; he did not want to have institutions such as NCWC as enemies, since they represented the American curia and had a strong influence in American politics, favored neutrality and could have a negative effect on his reelection.

This was, without doubt, a notably discouraging scenario for the commissioners of the Aguirre Government to try to prosper within New York's political and Catholic circles. But the SCW had still not come to an end and the Basque delegates had to keep their hopes up. Thus, with the help of Manuel Ynchausti (a Basque-American landowner close to Basque nationalism), De La Sota and Irala, they settled in the Big Apple and founded a Basque delegation which established as its main objectives to counteract pro-Franco propaganda, to seek funding and, naturally, to try to convince Americans to lift the weapons embargo imposed on the Spanish republican government ${ }^{8}$.

In order to achieve these purposes, they tried to obtain the support from American Catholic public opinion, trusting their support would enable them to get closer to Roosevelt's government, and to thus be able to pressure him and convince him to revoke his support for the non-intervention policy in the SCW and, consequently, lift the embargo ${ }^{9}$. Since, according to them,

At that political moment and after the European crisis (...), the only one who could do something for Spanish Democracy was Roosevelt. If the fate of Spain's war is decided in Europe, Italy and Germany, with England, can impose their decision against our interests (...). The day the law on the embargo comes to an end is coming close and Catholics (Jesuits) are getting ready to stop it from being lifted ${ }^{10}$.

Thus, besides looking for funding, one of the first initiatives they carried out was to promote a propaganda campaign on the international Catholic community, the State Department and American public opinion. Its objective was to show that the alliance between the Spanish republican

\footnotetext{
7 López Zapico, 2008, p. 60; Alpert, 1996, pp. 12-20; Rey, 1997.

${ }^{8}$ Bosch, 2013,pp. 167-187.

9 Totoricagüena, 2003; Douglass and Bilbao, 1986, p. 341.

10 Antón Irala to José Antonio Aguirre, 10/5/1938, New York. Irargi. Bergara, Spain. GE-0041-05.
} 
government and the Basque government, integrated and lead by Catholics, was loyal to a democratically elected government.

At first, they operated more cautiously; they focused on exploring the scene, spreading copies of the Euzko Deya newspaper as well as other propaganda literature, which condemned, among other things, the ItaloGerman intervention in the war, the ideological persecution and the origins of the Basque national problem. Thus, they timidly approached the Americans, without demanding any commitment in exchange and, hence, were able to achieve the approval from a large proportion of influential personalities on social, political, economic and cultural fields, which consequently contributed to increasing overall support for the Spanish Republic $^{11}$. Soon thereafter, by order of the Aguirre Government, the New York delegates began to organize meetings with the American Catholic and political representatives, where they appealed to the contacts that the Basque diplomatic representatives in France had established with the European Christian Democratic political parties ${ }^{12}$.

The strategy worked out as in autumn 1938 meetings were already underway. One of the first meetings was with Francis X. Talbot, a proFranco Jesuit priest whom they tried to convince that the Spanish war was not a crusade against Marxism, but a fight between fascism and democracy. They showed him that the only possible democratic approach a Catholic could adopt towards this war was the Basque approach, that is, one that supports the legitimately elected government. Notwithstanding all Basque efforts, there was not much to be done due to Talbot's obstinate and conservative disposition, who only agreed to recommend to the editorial department of the Catholic journal, America, that it stop defaming the Basque government ${ }^{13}$.

They also contacted Henry L. Binsse, director of the Commonweal journal, whose personnel, following Jacques Maritain's thesis, had declared itself neutral, even though in private many defended the Basque behavior during the war against the traditional, authoritarian and militarized Catholic insurgents ${ }^{14}$. Despite their neutrality, Binsse's sympathy

11 Propaganda file of the Basque Government Delegation in New York, 1938, New York. Irargi. Bergara, Spain. GE-0041-05; San Sebastián, 1991, p. 33.

12 Cal, 2012, pp. 203-204; Arrieta, 2009, p. 202.

13 Antón Irala to José Antonio Aguirre, 9/21/1938, New York. Irargi. Bergara, Spain. GE-0041-05.

14 Zanca, 2009, p. 159. 
towards the Basques was evident; he advised them that, in order to obtain the support from the Catholic hierarchy, before meeting with the NCWC representatives, they should issue a statement to all American Catholics through Verdier's Comité National Catholique d'accueil aux Basques ${ }^{15}$.

Following Binsse's advice, the Basques contacted William Montavon from NCWC, who was known for condemning the communist persecution in republican territory and for translating to English the letter the Spanish bishops wrote in 1937, where several aspects of the war were distorted ${ }^{16}$. The Basques knew that Montavon was a card they could use in their favor, but they weren't aware that he did not have a large margin of action before the pro-Franco Michael J. Ready (secretary of the NCWC). In fact, the latter had criticized Montavon for publicly condemning the bombardments and the outrage during the war, and for criticizing the American government. Montavon was finally pushed aside after Ready's visit to Spain, where the latter became convinced that he had to support the insurgents in order to protect his country from communism ${ }^{17}$.

Despite their skepticism about the meeting with Montavon, the Basque delegates moved forward requesting full collaboration from the NCWC in the context of an assistance plan for Basque refugees. To Irala's surprise, during the meeting, Montavon asked for explanations regarding their relationship with the Basque nationalist José Luis de la Lombana, who had participated in activities of the communist association Washington Friends of Spanish Democracy, which supported Juan Negrín's republican government ${ }^{18}$. Irala's embarrassment was notorious; he needed to dissociate his government from any type of action the former could have unilaterally undertaken that could affect the level of catholicity of the Basque government ${ }^{19}$. But Montavon was distrustful and temporarily shut the door to the Basques from the NCWC, since, even if they

15 Antón Irala to José Antonio Aguirre, 9/28/1938, New York. Irargi. Bergara, Spain. GE-0041-05.

${ }_{16}$ González, 2012, p. 321; On the collective letter of the Spanish bishops: Redondo, 1993 , p. 310.

17 González, 2012,pp. 329-330.

18 The Basque Delegation to William Montavon, 10/3/1938, Washington DC; American Catholic University Archive (ACUA), National Catholic Welfare Conference (NCWC), International Affairs, Spain 1938-1964, Basques, Box 51, Folder 11; Anasagasti and Erkoreka, 2013.

19 The Basque Delegation to William Montavon, 10/3/1938, Washington DC. ACUA, NCWC, Spain 1938-1964, Basques, Box 51, Folder 11. 
had given proof of their Catholicism and of the support they had from $\mathrm{Eu}-$ ropean Catholicism, they were still part of the Spanish republican government which, to them, persecuted, tortured and executed thousands of religious people ${ }^{20}$.

It was then that the Basque delegates began to pay greater attention to the Roosevelt Administration and its State Department. Thanks to Michael Straight, member of the US Department of Interior, Roosevelt's speechwriter and Ramón de la Sota' ${ }^{21}$ personal friend, they contacted Harry H. McBride, assistant to the Secretary of State, Cecil Wayne Gray; Thomas Corcoran, general secretary of the Democratic Party; and Eric C. Wendelein and Jay Pierrepont Moffat of the Office of European Affairs ${ }^{22}$.

During these meetings, the Basques weighed the prominent role they played in some of the Latin American republics, since many of those exiled had worked for the Basque government during the SCW, until it lost its territoriality, occupying some important government posts ${ }^{23}$. The aforementioned American political officers were particularly interested in what De La Sota had to say about the role the Basque exiles could play in Latin America in benefit of the American government, contributing to the fight against nazi, fascist and Japanese political-cultural penetration in Latin American republics ${ }^{24}$. During the 30's, this threat was perceived as a siege of European and Asian totalitarianisms against American democracy and, in this sense, the US Foreign Service agencies had initiated a defense device in case of a possible attack on American territory, planning the installation of military bases in the most vulnerable strategic points of the Atlantic and Pacific coasts ${ }^{25}$. Within this strategy, Basque exiles, united under president Aguirre, could play an important role thanks to their widespread presence in Latin America. As a counterpart for this collaboration, which as will be seen later became significantly important dur-

20 William Montavon to Michael J. Ready, 10/5/1938, Washington DC. ACUA, NCWC, Spain 1938-1964, Basques, Box 51, Folder 11.

21 Mota, 2016, p. 72.

22 Report on the organization of the US State Department, no date, no place. Irargi. Bergara, Spain. GE-0041-05; Jiménez de Aberasturi, 1999, p. 473; San Sebastián, 1991, pp. 37-38 and 61.

${ }_{23}$ Report no. 132, 2/15/1939, no place. Irargi. Bergara, Spain. GE-0041-05.

24 Weiner, 2012, pp. 107 and 112.

25 Report on the founding of a military collaboration in Latin America, no date, Washington DC. Rockefeller Foundation Archive (RFA), 4 NARA O-Washington DC Files, CIAA, Box 11, Folder 85 . 
ing WW2, the Basque delegation requested the removal of the weapons embargo and the mediation of the State Department before Franco's government in order to obtain the commutation of death sentences imposed on some Basque citizens.

The delegation repeated this request before different personalities on multiple occasions, as shown in the correspondence Ynchausti maintained with Mennen Williams, Cordell Hull and Frank Murphy throughout 193926. The Americans, however, almost always responded negatively, claiming these were not American citizens and their mediation would compromise US neutrality in the war ${ }^{27}$. This inattention, nevertheless, did not discourage the expectations of the Basque strategy. They continued sending information and keeping contact with the State Department, since a continuous and regular correspondence, as they believed, smoothened relations with the US.

During this same period, Aguirre sought to intensify contacts with the State Department. The delegation increased its personnel and began several propagandistic activities to foster Basque folklore and sport in the US ${ }^{28}$. Moreover, they carried out a propaganda campaign in the West, where they established good relations with the bishop of Reno, Thomas K. Gorman. They did not have the same luck in Idaho, where Irala and De La Sota encountered pro-Franco bishop Edward J. Kelly ${ }^{29}$. Thus, here they focused all their efforts in propaganda, boosting Euzko Deya and the establishment of new Basque nationalist settlements which, on the one hand, would reduce the traditional Carlist influence and, on the other hand, could be used to employ pastors in California,

${ }^{26}$ Mennen Williams to US State Department, 9/7/1939, Washington DC. National Archives and Records Administration (NARA). RG 59, State Department, box. 6415; G.S. Messersmith to Frank Murphy, 11/4/1939, Washington DC, NARA, RG 59, State Department, Box. 6416, Leg. 852.00/9370.

${ }^{27}$ In the White House and the State Department there were exceptions regarding the American attitude adopted in the Spanish Civil War. In fact, President Roosevelt and his wife, Eleanor, were in favor of intervention and collaboration. Additionally, the relevance of the bombing of Guernica on American public opinion when valuing the contending sides must be mentioned, as a notable part of American society, close to Catholicism, was very critical of francoists and mobilized against it. To deepen these topics, see Bosch, 2012, pp. 109-228; Irujo, 2017.

28 Pedro Basaldúa to Antón Irala, 9/12/1938, París. Irargi. Bergara, Spain. GE0041-05; Ordaz, 1995, pp. 179-198.

${ }^{29}$ Bieter and Bieter, 2005, p. 96. 
Idaho and Nevada ${ }^{30}$. Finally, they planned the creation of a sub-delegation in Boise which, although still dependent on the New York delegation, would be in charge of activities in this area.

Moreover, Aguirre asked the New York delegation to reinitiate contact with the Catholic media. He wanted them to meet with the main communications media and the main Catholic institutions so they could redirect their opinions about the Basques and, hence, use their influence on president Roosevelt. Antón Irala, the main promoter of the pro-US policy during these years, supported this strategy. In fact, at the beginning of 1939, he had already told the Basque government in Paris about its potential:

Our power is extensive; I can tell you now, in a confidential and very discreet tone, that in no time not even the Cardinal in Boston will be able to oppose us and will follow the same path as New York. ${ }^{31}$

What is more, having seen that contacts with the State Department did not move as fast as expected, Irala decided to resume the 'Catholic card'. He was feeling optimistic, since besides his political contacts, he had obtained the sympathy from the influential pro-Franco cardinal of New York, Patrick Hayes, and was proud that his lobbying activities were finally starting to produce results ${ }^{32}$.

He resumed, consequently, contact with American Catholicism, leaving aside all those who were pro-Franco and focusing on sympathizers of the Basque government. He met with Cardinal George Mundelein, to whom he explained that the problem in Spain was similar to that in $\mathrm{Yu}$ goslavia, that is, a State composed of different federate nations that, as a consequence of the rise of unitary nationalism, had been subjugated. He tried to awaken their interest in exiled Basque children in France, trying to convince them to collaborate financially with the sustainability of these children's colonies. Moreover, he showed him Aguirre's approach on the dangerous influence of 'German paganism' on catholicism

30 José Antonio Aguirre to Manuel de la Sota, 1939, no place. Irargi. Bergara, Spain. GE-0041-05; On the shepherds Saitua, 2018, pp. 81-119.

31 Antón Irala to the Basque Government, 1939, París. Irargi. Bergara, Spain. GE0041-05.

32 Propaganda file of the Basque Government Delegation in New York, 1938, New York. Irargi. Bergara, Spain. GE-0041-05. 
in Spain, and the possible consequences this could have on Western democracies $^{33}$.

Within this context, the lehendakari (in Basque language: president), who was witnessing the absolute collapse of the republican army in Catalonia and the consequent advance of the insurgents, requested the presence of Antón Irala in France. They needed to organize the evacuation of Basque refugees in order to prevent a transoceanic emigration which, according to the Basque president, would complicate the return of the exiles in the hypothetical case there was a war at European scale and totalitarian regimes -including Franco's regime - would be defeated ${ }^{34}$. This evacuation implied a significant mobilization of people and resources outside of the country, exceeding the capacity of a Basque government which lacked financial resources to maintain refugees in France ${ }^{35}$. It was thus how, in January 1939, following Aguirre's indications, Ramón de la Sota, resumed contact with Ready from the NCWC, to whom they asked for financial assistance for the exiles:

The Basque refugees wherever they are in-exile, are under the jurisdiction and assisted by the Basque government, who follows a policy of educating them in accordance with the wishes and instructions of their parents. Owing to the catholicism of the Basque people, the problem of the catholic education of the children has been solved by organizing colonies supervised by Basque priests and Basque catholic teachers, and with the help and cooperation of catholic societies formed for the purpose ${ }^{36}$.

The NCWC decided not to assume any commitments, to dodge the delegation's request and to keep its approach unchanged, in favor of the national side. This, however, did not lead to a rupture of relations. On 1 April 1939, once the SCW was officially over, Basques tried to contact this organization once again to request their support for their project of es-

33 Pedro Basaldua to Antón Irala, 1/25/1939, París. Irargi. Bergara, Spain. GE0041-05.

34 José Antonio Aguirre to Manuel de la Sota, 1939, no place. Irargi. Bergara, Spain. GE-0041-05.

35 José Urresti to José Antonio Aguirre, 2/15/1939, New York. Irargi. Bergara, Spain. GE-0041-05.

36 José Urresti to Michael J. Ready, 2/4/1939, New York. ACUA. NCWC, International Affairs, Spain 1938-1964, Basques, Box 51, Folder 11. 
tablishing an American division of the International League of the Friends of the Basques ( $L I A V$, in Spanish), a humanitarian-assistance organization with political responsibilities which in France operated as a legal coverage for the Basque government. In August 1939, Ynchausti had already tried to create a federal aid committee for Basques in Canada, which could collect funds to maintain Basque humanitarian assistance organizations, but the opposition from Cardinal Villeneuve had forced him to look for other allies ${ }^{37}$.

It was then that the Basque-Philippine personally tried to implement the LIAV in the US, approaching the Jesuit Wilfrid Parsons, the journalist John LaFarge and the first lady, Eleanor Roosevelt ${ }^{38}$. He also contacted the archbishop of Detroit, Edward Mooney, to whom he explained the objectives and responsibilities of the LIAV, highlighting the possibility that it could become a representative organ of the Basque government in the US $^{39}$. Mooney's delay to reply incited Ynchausti, who had a good reputation among the American episcopate, to take further action. In fact, he proposed to himself that during the United States Conference of Catholic Bishops in November 1939, the NCWC would approve a memorandum called «Proposed Organization. American Section of the International League of the Friends of the Basques», where it justified in financial, political and humanitarian terms why the American division of the LIAV had to be established ${ }^{40}$. Mooney did not commit himself and this issue was not discussed in the NCWC meeting. As a consequence, Ynchausti did not manage to create the LIAV division; however, he did not desist in his efforts. In January 1940, he rented an office at the Rockefeller Center where he established an information center at the service of Basque immigration which, in the end, became essential for the Basque government's contacts in exile ${ }^{41}$.

After the US government pursued a non-intervention policy during the SCW-a policy that was promoted by highly influential officers within the State Department who only looked at protecting American interests

37 Larronde, 1998b, p. 115.

38 Ibid., pp. 103-104.

39 Larronde, 1998a.

40 Proposed organization. American Section of the International League of the Friends of the Basques, 10/3/1939, New York, ACUA. NCWC, International Affairs, Spain, 19381964, Basques, Box 51, folder 11, pp. 1-4.

${ }^{41}$ Larronde, 1998b, p. 111. 
in Spain-on 1 April 1939, they furthermore recognized Franco's government, generating widespread dissatisfaction among American liberals, «our diplomats remain hog-tied by expediency, a self-imposed strangulation by the Old School ties» ${ }^{42}$. This, moreover, led to a change in Basque politics in the US; they no longer focused on trying to stop Franco's victory in the war, but now they concentrated instead on trying to show the US that they had legitimized Franco's government, which was an essentially anti-democratic regime. Nonetheless, Americans still justified their recognition of the «nationals' government» claiming that Franco's army controlled all of the country and, hence, it was indispensable to normalize diplomatic relations with its regime, although not without also adding that:

The maintenance of normal diplomatic relations by this government with other governments throughout the world does not, of course, imply either approval or disapproval of their policies or actions. ${ }^{43}$

During the period prior to WW2, Basque delegates continued with the same strategy they had implemented during the Civil War, that is, to try to obtain supporters for their cause within the State Department and New York's liberal sectors in society, as well as to obtain funding sources for their refugees. However, the outbreak of WW2 in September 1939 forced the Basque government to rethink their strategy in less than a year since France's government, who had until then collaborated with the Spanish republican exiles, decided in May 1940 to keep distance in order to maintain Franco's neutrality and avoid the emergence of another military front in the Pyrenees, which could have occurred had Spain entered the war on Germany's side. Hence, the situation of Basque exiles in France became significantly difficult and, even if the Basque government decided to support the French unconditionally, the German occupation and the constitution of a pro-Axis government under general Pétain, invited the Basques to search for other partners in their fight against totalitarianism ${ }^{44}$.

42 Jay Allen to Harold Ickes, /328/1939, Washington DC, NARA, RG 59, US State Department, box 6415, folder 852.00/9171. Moradiellos, 2001, pp. 89 and 95-103. Avilés, 2006, pp. 11-27.

${ }_{43}$ George Messersmith to Guy E. Shipler, 4/27/1939, Washington DC, NARA, RG 59, US State Department, box 6339, folder 852.00/9171. 2009.

${ }_{44}$ Moradiellos, 2007; Wigg, 2005; Payne, 2008; Gluckstein, 2013; Ros, 2008. Ros, 
In this context, Aguirre had disappeared into occupied Europe, leaving the Basque government acephalous. To alleviate this situation, Irujo created the National Euzkadi Council ( $C N E$, in Spanish) in London, where he had access to the secret services of both Great Britain and general De Gaulle's Free France, with which he reached a collaboration pre-agreement that, however, did not finally come into being. At the same time, the New York delegates strengthened their relation with the still neutral US government which, given the European context, showed itself willing to listen to the Basque offers of collaboration. These offers became even more relevant when the lehendakari reappeared in the Big Apple in autumn 1941; after having clandestinely moved along occupied Europe under the fake identity of Panama diplomat José Álvarez Lastra, Aguirre finally settled in New York, where he set up his operations center.

Aguirre's establishment in Manhattan marked a point of inflection for Basque politics in exile. On the one hand, it focused its attention on maintaining a preferably close relationship with the American Giant and, on the other hand, it did not leave out the already forged connections with the British and the French. A three-sided game that took place at a key moment, firstly, because during that summer, United States and Great Britain had signed the Atlantic Charter with the objective of working jointly in order to achieve a durable peace that would respect the rights of all people to choose their own form of government (a fundamental political principle which Basques could use in the future); and, secondly, because in December 1941 the Japanese Imperial army attacked the naval base in Pearl Harbor, which finally triggered America's involvement in WW2 ${ }^{45}$.

It seemed, under those circumstances, that the international context favored Basque interests, who were striving to win support from the US. If the State Department had initially tried to distance itself from any official relation with minor institutions, once USA entered the war, Roosevelt's Administration became more willing to listen to all sorts of collaboration offers. Aguirre thus seized this opportunity and introduced himself as the charismatic leader of a political organization that was deeply inserted in Latin America and with high influence capacity over Latin American Catholicism ${ }^{46}$. In this sense, he used this image, just like his delegates had done during the SCW, to show himself as an ally that could offer the BIS

45 Beevor, 2012, p. 349. Kennedy, 2005, p. 609.

46 Mees, 2006, p. 43. 
to American intelligence services in order to help them counteract fascist propaganda in America's backyard ${ }^{47}$.

\section{The BIS: the tip of the balance in Basque pro-US politics during WW2}

Aguirre settled in New York thanks to Ynchausti, who also put pressure on Columbia University with lucrative donations so it would hire the Basque president as a lecturer ${ }^{48}$. From this position, Aguirre had exclusive access to the US political field, allowing him to win influential contacts within the State Department and the Roosevelt Administration. One of these was Carlton Hayes, Director of the History Department at Columbia University, Roosevelt's personal friend and future US ambassador in Madrid; he introduced Aguirre in several different political, intellectual and diplomatic circles, both within American society as well as within European Catholic exiles ${ }^{49}$.

Despite having an excellent patron to access the highest ranks in American power, relations with some agencies such as the State Department were still difficult. Sumner Welles, subsecretary of this organism, showed little interest in the Basque rapprochement, since not only he considered this group of little leverage, but moreover, he believed that a relation like this could only irritate Franco. Neither did George Summerlin, chief of protocol for the White House, favor contacts with Aguirre's group, which he considered a minority, not very representative and not well connected to Spanish political figures relevant in Washington $\mathrm{DC}^{50}$.

The lehendakari thus decided to relaunch his «Catholic strategy», focusing this time on vice-president Henry A. Wallace, an intensely Catholic politician from the Democratic Party who was also favorable to the Basque cause. Wallace was widely popular and had large support, even though certain political circles criticized him for positioning himself within the most leftist side of the Democratic Party ${ }^{51}$. He was interested

47 Report no. 132, 2/15/1939, no place. Irargi. Bergara, Spain. GE-0041-05.

48 «Nomination for appointment», 9/23/1941, New York, Columbia University Archives (CUA), Historical Biographical Files Collection, Box 77, Folder Aguirre.

49 Mees et al., 2014, p. 446.

50 Jiménez de Aberasturi and Moreno, 2009, pp. 403-404.

51 Graham, 2009. 
in Latin American issues and, more importantly, he had made Aguirre's ideas his own regarding the ideological nature of WW2. This mutual understanding favored their strengthening of political ties, although it also provoked mistrust among the US government and its different agencies, which tried all sorts of maneuvers to erode this relation ${ }^{52}$.

These difficulties encouraged the Basques to explore other options. On the one hand, Nelson Rockefeller's CIAA, an American agency concerned with security issues in the Western hemisphere; and on the other hand, the COI, an intelligence and propaganda agency created by Roosevelt in July 1941 and directed by coronel William J. Donovan ${ }^{53}$. Contacts with the CIAA helped the Basque organization present a collaboration project where they vowed to carry out propaganda and espionage activities to help USA and through which they put all their resources at their disposal, especially the BIS, to contain the Axis in Latin America, in exchange for funding for Basque exiles ${ }^{54}$.

The negotiations for this proposal, by means of which Basques intended to establish a collaboration agreement with America, remained on standby due to the reticence of some sectors of the Roosevelt Administration which thought it was counterproductive to entrust this type of activities to a foreign group ${ }^{55}$. However, these efforts were rebooted when Americans saw the potentiality of the BIS, due to the information it provided the British intelligence services. In the midst of negotiations with the Americans, Basques had already begun to work for the British offering excellent results, such as obtaining the secret instructions that Franco's navy should follow in case Spain would enter the war.

Consequently, American intelligence agencies decided to disregard those sectors from the Roosevelt Administration that were reticent to cooperation and, without having formal contact with the Basques, they decided to try to benefit from the results the latter had achieved for the British in counterespionage matters. In fact, using the BIS for these activities had been the work of William Stephenson, director of the Secret Intelligence Service (SIS) of the British Security Coordination (BSC), which had contacted Aguirre in November 1941 to extend BIS activities in America.

52 Jiménez de Aberásturi, 1999, p. 476.
53 Liptak, 2009, pp. 4-5.
54 Jiménez de Aberásturi, 1999, p. 477.
55 Mees et al., 2014, p. 450.

https://doi.org/10.1387/hc.20374 
But the US entry in the war froze these contacts. The COI, which centralized American intelligence services with the purpose of directing all intelligence activities in Latin America, removed the BSC from the Latin American scene. The influential pressures of the director of the FBI, J. Edgar Hoover, were also decisive in this context; distrustful of foreign espionage activities in America, he intended to control and follow closely these undertakings. Such pressures led to one result; in February 1942, the Roosevelt Administration promoted a legislative reform that compelled all foreign agents who wanted to operate in USA to be registered in the Justice Department. This law weakened the BSC and, hence, Americans were able to direct all intelligence and counterespionage activities in the Western hemisphere ${ }^{56}$.

This centralization led to the realignment of the organizational structures of American information agencies, which opened their doors to a closer collaboration with the Basques. Thus, in spring 1942, the lehendakari Aguirre and Manuel De La Sota met in New York with the COI, an agency which disappeared in June that year and that preceded the OSS, with which the Basques, as previously mentioned, had already reached a pre-agreement of collaboration to counteract totalitarian propaganda from the Axis ${ }^{57}$. This pre-agreement had, moreover, established that the BIS would coordinate all of its activities, and included freedom of action, safe-passage and confidential communication systems with American encryptions. It would concentrate on pro-Allied propaganda, on obtaining information on pro-Axis circles, and on carrying out espionage services in Latin America.

Notwithstanding the pre-agreement with the OSS, by the time summer arrived in 1942, there was still no firm agreement. Some researchers have indicated that the agreement must have been signed somewhere along the month of May 1942, but the recently declassified documentation does not shed light on this issue ${ }^{58}$. In fact, it is possible that it was not signed on this date since, observing the correspondence between William Donovan and Cordell Hull as well as the information that appears in the lehendakari's diary, it can be verified that this so-called 'agreement' was a much more complex process which involved more than a few simple conversa-

56 Weiner, 2012, p. 152; Law, 1982, p. 367.

57 «Memorandum about José Antonio Aguirre», NARA, Washington DC, 6-5-1942, RG 226, OSS Files, Entry 106, Box 32, Folder 151.

58 Mota, 2016, p. 130-134. Irujo, 2012, p. 123. Mees et al., 2014, p. 452. 
tions between Aguirre and Donovan's agency ${ }^{59}$. Otherwise, it cannot be explained why on 3 July 1942 Donovan pressured the secretary of state to support the cooperation project between the OSS and the BIS, warning him that «unless this functioning machinery can be set up, I fear we will be unable to profit by this very advantageous opportunity ${ }^{60}$.

In fact, Donovan's negotiations extended over time due to the internal barriers and criticisms he encountered. Hence, throughout autumn 1942, he concentrated on contacting his most direct officers in order to assess the support he had to close a final agreement with the Basques. On 24 November 1942, coronel David Bruce, OSS chief of operations in Europe, communicated to Donovan that the agency should study whether to commit themselves to collaborate with an organization that opposed the Spanish regime, that not only had requested for encryption codes for correspondence sent to Spain and radio-transmitters to carry out joint activities, but that had also requested weapons and explosives ${ }^{61}$.

As is revealed on the archival sources, the OSS maintained its reservations to the point that it only agreed it would finalize a definite agreement in the future; the agency was not as entirely convinced of committing itself with the Basques as it had appeared, which can be seen in the following paragraph:

The question of our (Washington Headquarters O.S.S.) making contacts with subversive elements that are directly opposed to the present Spanish Government is one of high policy. The events of the immediate future will, no doubt, indicate whether or not Spain will in some way or another termined to resist all German pressure, including that which may be exerted upon her for the use of air-bases in Southern Spain, then it would be my personal belief that it would be a mistake to jeopardize our relations with Spain by attempting to enter joint operations with revolutionary or independent groups such as represented by Aguirre and his Independent Basque following ${ }^{62}$.

59 José Antonio Aguirre, «entrada del viernes», Diary 1941-1942, May 22, 1942.

60 William Donovan to US Secretary of the State, 7/3/1942, Washington DC, Support Provided to Basque Movement and Intelligence Service, OSS Files, FOIA 2013/12/18, CIA-RDP13X00001R000100020009-3.

${ }^{61}$ Oiarzabal and Tabernilla, 2017, p. 54.

62 David Bruce to colonel Donovan, 11/24/1942, Washington DC, Support Provided to Basque Movement and Intelligence Service, OSS files, FOIA 2013/09/16, CIARDP13X00001R000100220005-5. 
The issue about the agreement persisted until mid-1943, when finally, Basques chose to collaborate with the OSS and the FBI, despite being tempted by substantial amounts of money by the United States Army G-2. By that time, the FBI not only controlled almost all espionage activities in America, but the OSS had moreover lost power, prestige and influence $^{63}$. In this context, Basque authorities decided to work for Hoover's agency in Latin America, and for the OSS and the American army in Europe.

In Latin America, the BIS limited its contacts to the FBI, in particular to its Legal Attachès, that is, the legal aggregates of the federal police in American embassies, who were the ones who gave the Basques its missions and instructions ${ }^{64}$. During the first years of WW2, the BIS' main mission was to spy on pro-Axis organizations and to carry out counterpropaganda activities, but as several reports from the FBI confirm, as the war progressed, it also began to increasingly look at communist activities, especially those of Spanish political exiles ${ }^{65}$. Thus, while the BIS obtained information on pro-Axis supporters, controlling Nazi movements and operations, and examining the crews of Spanish ships, it also investigated communist activities in Bolivia, Uruguay, Paraguay and Chile. The BIS thus followed Antón Irala's orders, who was then the main contact between the Basques and American intelligence agencies and who had shown the Americans that communism could, in the near future, become their main problem in Latin America,

Both such movements, namely, Communist and Fascist, have for their immediate aim the destruction of North American influence in Latin America and the ultimate launching of revolutionary governments along the Soviet lines. ${ }^{66}$

Thus, in summer 1943, as worries of an invasion from the Axis powers began to fade away, German espionage ceased to be United States' only concern. On the other hand, the issue about communism began to in-

${ }^{63}$ Mota, 2016, pp. 158-161.

64 Smith, 2009, p. 103; Weiner, 2012, pp. 161-162; Theoharis, 1999, p. 338.

65 Memorandum on the Basque organization-Latin American Matters, 3/14/1944, New York, FBI Archive, Basque Intelligence Service (BIS), Section II. tion II.

${ }^{66}$ Confidential informant to J.E. Hoover, 4/24/1944, Cuba, FBI Archive, BIS, Sec- 
crease which, according to the FBI, could potentially damage the image of the US as safeguard of democracy that the Roosevelt Administration had built both in Europe and Latin America ${ }^{67}$. To stop this image from being corroded, Hoover promoted a political lobby in Washington to convince the government that the support Stalin was obtaining in the Western world was weakening democracy ${ }^{68}$. Moreover, he believed that the FBI should prioritize monitoring communist activities in Latin America because, as confirmed by the BIS' reports, these had already achieved significant influence in Mexico.

In this context, Antón Irala met with the FBI's legal aggregate in May 1944 in Mexico to agree on the details of the BIS' collaboration. The American agent requested 300 Basques who lived in Mexico City and other large cities to use as informants, reserving the agency's the right to nullify the agreement in case the results were deemed unsatisfactory. Such demands, together with the scarce funding provided for their operations, infuriated Irala, who believed Americans undervalued the BIS' abilities $^{69}$. In fact, he notified the lehendakari who urged him notwithstanding to continue with the project, even if the Basque government had to defray their own operations. Nevertheless, on November 1944, the FBI noted that the BIS' performance was too low and they had to, therefore, significantly decrease its funding ${ }^{70}$.

Consequently, contacts with the FBI were put on hold and Irala resigned from his position as BIS coordinator in Latin America, moving to France to incorporate as the BIS connection in an OSS mission which intended to create an information network between the Pyrenees, France and Belgium after the Normandy landings. Taking advantage of this collaboration between the BIS and the OSS, the FBI found justification for its actions. Today we know, however, that the director of the FBI suspected the BIS, as he would of any organization related with Donovan's OSS; Hoover believed the OSS was infested with Stalin's agents who, besides defeating Hitler, also wanted to obtain information on the internal situation of United States' agencies ${ }^{71}$.

${ }^{67}$ Friedman, 2003, p. 159. Yeadon and Hawkins, 2008, pp. 47 and 163-191.

68 Weiner, 2012, p. 163.

69 Jiménez de Aberasturi, 1999, p. 478.

70 Antón Irala to José Antonio Aguirre, 11/14/1944, New York, FBI Archive, BIS, Section VII, NND-267468, Leg. 64-23117.

71 Weiner, 2012, p. 171. 
In any case, the OSS European mission which Irala finally joined concentrated on developing an information system in France and Belgium that would obtain war information in Latin America independently of the FBI, and on creating a clandestine mailing network that would connect Spain and United States through Portugal ${ }^{72}$. Neither the State Department or the Office of European Affairs approved this project which was meant to be led by Irala; however, this did not stop the OSS and the BIS from working together in other operations, such as Airedale, a sabotage mission to fight against the last Nazi strongholds in the French Aquitaine region ${ }^{73}$.

In this context, in summer 1944, the Allies liberated Paris. Aguirre thought they could then begin to reap the benefits his organization had harvested, that is, the Allies' moral commitment to intervene in Spain to defeat Franco in order to liberate Europe from totalitarian domination since, after all, the Basques had helped them in their military efforts. In fact, it could not be any other way according to the Basque president after Roosevelt endorsed the «people's right to self-determination doctrine» ${ }^{74}$.

Returning to Euskadi (Basque Country) seemed now plausible to Aguirre, who relied on certain information of privilege from Spencer Phenix, an agent of the OSS in charge of Iberian Peninsula matters in Washington DC. The latter, who considered Franco's regime as unstable, had pointed out to Donovan the need to support the Basques as soon as possible so they could lead a clandestine movement that would ease the transition to democracy in Spain and, thus, avoid chaos, civil war and anarchy. The Roosevelt Administration, he argued, was responsible for the future of democratic movements in Spain, with whom they had taken on a commitment, by means of which they could not allow them to perish under Franco's or communism's oppression. Hence, the best option was that the OSS intervened in Spain to help establish a democratic government with the assistance of Aguirre's organization, who had already begun contacts with the conservative politician, Miguel Maura, to reorganize and lead the Spanish republican government. Moreover, he insisted, even if there were

72 Spencer Phenix to William J. Donovan, 11/25/1944, no place, RG 226, OSS Files, Entry 210, Box 391, WN 7169.

73 William A. Kimbel to Spencer Phenix, 9/27/1944, no place, NARA, RG 226 OSS files, Entry 210, Box 300, WN 12813, Leg. C12813/008; Mota, 2017, pp. 145-162. 1944.

74 José Antonio Aguirre, «Misión de América», Euzko Deya (Mexico), March 1, 
no guarantees that there could be a peaceful political transition in Spain, Phenix warned Donovan that.

The consequences of a hands-off policy could be so disastrous not only for Spain but also for the cause of democracy and liberty in other parts of the world, that the seizing of even a forlorn chance would seem worthwhile. ${ }^{75}$

Finally, even if they agreed that it was «Time for change in Spain», the State Department advised not to interfere directly in Spanish internal political matters as they did not want Francoist authorities to suspect that the OSS aimed to intervene Spain in order to defeat Franco ${ }^{76}$.

Nevertheless, Phenix's support for the Spanish democratic cause confirms that the gradualist strategy promoted by the lehendakari, that is, the one that intended to search for a solution to the Spanish problem as a way of returning the Basque government to its peninsular territory, was wellreceived by some circles within American political power, inasmuch as the Basque political organization introduced itself as an effective political instrument to help fight against totalitarianism, defeat Franco and establish a new political regimen contrary to fascism and communism ${ }^{77}$.

\section{Conclusions}

In conclusion, seeking the protection from the United States was a constant for the Basque government during the Civil War and WW2. Maintaining official and unofficial relations, both with American congressmen and politicians, as well as with agents from the State Department and other related agencies, demonstrates that Basque leaders highly valued the American political scene as fundamental to achieve their objectives of recovering democracy and Basque self-government.

In this sense, in the deployment of their Atlanticist strategy, the New York delegation of the Basque government relied on the collaboration of the associations of Basque communities that had emigrated to Amer-

\footnotetext{
75 Spencer Phenix to William Donovan, 12/16/1944, Washington DC, NARA, RG 59, State Department, Box 5234, Leg. 852.00/12-1944.

76 Paul T. Culbertson to James C. Dunn, 12/28/1944, no place, NARA, RG 59, State Department, Box 5234, Leg. 852.00/12-1944.

77 Mees, 2006, p. 79.
} 
ica, many of which supported Basque nationalism. Nevertheless, the Basque leaders in charge of the Atlanticist political strategy did not use these Basque-American immigrant groups as their supportive axis of their policies in the US, nor did they use them as their main instrument to exert pressure on the political scene. As a matter of fact, they preferred using the New York delegation and the individual contacts with American politicians and European exiles. The fact that this delegation was located in New York, as opposed to California, Nevada, Idaho or Oregon, where there was a stronger presence of Basque citizens, is symptomatic, indicating that Basque leaders prioritized basing their institutions in strategic cities, close to American political power.

During these years, the relationship between the Basque government and USA was altogether asymmetrical. Whereas Basques were continuously showing interest in this relationship, Americans oscillated, depending on the possible strategic advantages they could obtain in the international context. Roosevelt's democrat presidency (1933-1945), which covers the period studied in this article, was the most significant for Basque exiles; during this period, it was plausible that the US took action against Francoism both in diplomatic and military terms, in the heat of the measures taken by the Allies against the Axis and its collaborators during WW2 ${ }^{78}$. In fact, there was an effective collaboration between Basques and Americans through their intelligence services. Nevertheless, the overall tone of its policy was to ensure its economic and military interests in the Iberian Peninsula whilst continuing their relation with the Basques, of whom they were mostly interested in the information the latter could provide about the Axis and communism, both in America and within Spain, without offering any sort of political compensation in exchange.

The Atlanticist strategy did not have a fully structured plan, but instead those in charge of the Basque government's foreign activities in United States tried to make the most of different opportunities that were presented to them depending to the international context of the time. Hence, the relation between the Basque government in exile with differ-

78 Throughout the Cold War there would be criticism within Basque nationalism towards agreements and relations with the Americans; in other words, that there were also Basques who disagreed with the Basque Government's policy, such as Manuel Irujo or Jesús María Leizaola. Nevertheless, the Aguirre's line remained until his death in 1960. On the change of the relationships: Irujo, 2012; Mota, 2016; Azurmendi, 2013; De Recondo and De Recondo, 2011. 
ent agencies of the US government, as well as with different lobbying political platforms, labor unions and other organizations of this country, were subordinated from the start to the strong restrictions imposed by the changing international context. In this sense, the Basque government offered the US government a series of benefits to show themselves as an attractive partner. On the one hand, it introduced the BIS as a friendly organization that could collaborate in propaganda and espionage activities. This was, without doubt, the main asset a small government in exile could offer to the American giant, even though this did not imply they would receive in exchange the rewards they expected: the American intervention in Spain, the restoration of democracy and the possibility of obtaining an independent State. On the other hand, the Basque government showed itself willing to contribute to establish a moderate - and non-communistdemocratic regime in Spain, something United States had always considered when thinking about a political change from Franco's dictatorship. In effect, during the majority of this chronology of relations, Basque politicians could not offer much more, and once WW2 was over and the Cold War had begun, these offers became insufficient.

\section{Bibliography}

ALONso, Teresa, La economía de entreguerras. La gran depresión, Akal, Madrid, 1990.

ALPERT, Michael, «Del embargo a la neutralidad: Estados Unidos y la guerra civil española», Historia 16, 248, 1996, pp. 12-20.

ÁlvarEz, Óscar and SANZ, Eneko, «El exilio institucional: el Gobierno autonómico vasco y sus delegaciones en el exterior», Eusko IkaskuntzaEuskoNews, 564, 2011, pp. 2-4.

Anasagasti, Iñaki and ErkoReKa, Josu, A Basque Patriot in New York: José Luis de la Lombana y Foncea and the Euskadi Delegation in the United States, Center for Basque Studies, Reno, 2013.

ANDERSON, James M., The Spanish Civil War: A History and Reference Guide, Greenword Press, Westport, 2003.

ARrieta, Leyre, «Landaburu, el alavés europeísta», Sancho el Sabio, 31, 2009, pp. 199-220.

ARRIETA, Leyre, Estación Europa. La política europeísta del PNV en el exilio (1945-1977), Tecnos, Madrid, 2007.

AviLÉs, Juan, «Las potencias democráticas y la política de No Intervención». Historia del Presente, 7, 2006, pp. 11-27. 
AzURMENDI, José Félix, Vascos en la Guerra Fría ¿víctimas o cómplices? Gudaris en el juego de los espías, Ttarttalo, San Sebastián, 2013.

Beevor, Antony, La Segunda Guerra Mundial, Pasado y Presente, Barcelona, 2012.

BIETER, John and BIETER, Mark, Un legado que perdura. La historia de los vascos en Idaho, Gobierno Vasco, Vitoria-Gasteiz, 2005.

Bosch, Aurora, Miedo a la democracia. Estados Unidos ante la Segunda República y la guerra civil española, Crítica, Barcelona, 2012.

Bosch, Aurora, «Entre la democracia y la neutralidad: Estados Unidos ante la Guerra Civil española», Ayer, 90, 2013, pp. 167-187.

CAL, Rosa, «Alberto Onaindia, propagandista contra el franquismo», Miguel Hernández Communication Journal, 3, 2012, pp. 193-215.

DECOnde, Alexander y BuRns, Richard D., Encyclopedia of American Foreign Policy, Charles Scribner's Sons, New York, 2001.

De Recondo, Jon and De Recondo, Anne Marie, A los 75 años de Gernika. Un testimonio, Ganboa, Andoain, 2011.

Douglass, William A., y BILBAO, Jon, Amerikanuak. Vasco en el Nuevo Mundo, UPV-EHU, Bilbao, 1986.

ÉGIDO, Ángeles, «Los compromisos internacionales de un país neutral», Historia del Presente, 7, 2006, pp. 27-42.

EstombA, Fernando, «El equipo Euzkadi: del mito político a la realidad histórica (1937-1939)», Historia Contemporánea, 35, 2007, pp. 791-816.

Friedman, Max P., Nazis and Good Neighbors: The United States Campaign Against the Germans of Latin America in World War II, Cambridge University Press, New York, 2003.

GARCÉs, Joan E., Soberanos e intervenidos. Estrategias globales, americanos y españoles, Siglo XXI, Madrid, 1996.

GARRIDO, Iñaki and LEKUONA, Aitziber, Las raíces del árbol en el exilio. Las biografías de los consejeros del primer Gobierno de Euzkadi, IVAP, Oñati, 2006.

GLUCKSTEIN, Donny, La otra historia de la segunda guerra mundial: Resistencia contra Imperio, Ariel, Barcelona, 2013.

GoIOGANA, Iñaki and BernARdo, Iñaki, Galíndez: la tumba abierta. Guerra, exilio y frustración, Fundación Sabino Arana, Bilbao, 2006.

GologanA, Iñaki, «José Antonio Aguirre, profesor de la Columbia University», in AsCunCE, José Ángel (ed.), Exilio y Universidad (1936-1955), Saturraran, San Sebastián, 2008, pp. 599-643.

GoIoGANA, Iñaki, «Antón Irala y la primera delegación del Gobierno Vasco en los EEUU», Hermes, 31, 2009, pp. 84-90.

GonZÁLEZ, José L., «La guerra civil española y la conferencia de obispos norteamericana», Hispania Sacra, LXIV, Extra I, 2012, pp. 315-341. 
Knocking on America's door. Basque Foreign Politics in the US during the Spanish Civil...

Graham, John M., Henry A. Wallace: his Search for a New World Order, University of North Carolina Press, Chapel Hill, 2009.

Granja, José L., El siglo de Euskadi. el nacionalismo vasco en la España del siglo XX, Tecnos, Madrid, 2003.

IRUJO, Xabier, Expelled from the Motherland. The Government of President Jose Antonio Agirre in Exile, 1937-1960, Center for Basque Studies-University of Nevada, Reno, 2012.

IRUjo, Xabier, 26 de abril de 1937. Gernika. Crítica, Barcelona, 2017.

JACKSON, Gabriel, La República española y la guerra civil: 1931-1939, Crítica, Barcelona, 1999.

JENKIns, Philip, Breve historia de Estados Unidos, Alianza, Madrid, 2002.

JIMÉNEZ DE ABERÁSTURI, Juan C., De la derrota a la esperanza, políticas vascas durante la Segunda Guerra Mundial (1937-1947), IVAP, Oñati, 1999.

JiMÉNEZ DE ABERÁSTURI, Juan Carlos and MORENO, Rafael, Al servicio del extranjero. Historia del Servicio Vasco de Información (1936-1943), Antonio Machado Libros, Madrid, 2009.

KenNEDy, David M., Entre el miedo y la libertad. Los EEUU: de la Gran Depresión al fin de la segunda guerra mundial (1929-1945), Edhasa, Barcelona, 2005.

LARronde, Jean-Claude, Exilio y Solidaridad. La Liga Internacional de Amigos de los Vascos, Instituto Bidasoa, Villefranque, 1998.

LARronde, Jean-Claude, Manuel de Ynchausti, un mecenas inspirado (19001961), Instituto Bidasoa, Villefranque, 1998.

LAw, Yuk K., «The Foreign Agents Registration Act: a New Standard for Determining Agency», Fordham International Law Journal, 6, 1982, pp. 365-382.

LIPTAK, Eugene, Office of Strategic Services 1942-45. The World War II Origins of the CIA, Osprey, New York, 2009.

LóPEZ ZAPICO, Misael A., Las relaciones entre Estados Unidos y España durante la Guerra Civil y el primer franquismo (1930-1945), Trea, Gijón, 2008.

MeEs, Ludger, El profeta pragmático: Aguirre el primer lehendakari (19391960), Alberdania, Irún, 2006.

MeEs, Ludger et al., La política como pasión. El lehendakari José Antonio Aguirre (1904-1960), Tecnos, Madrid, 2014.

Miralles, Ricardo, «La incidencia de la situación internacional en la guerra de Euskadi, 1936-1837», Historia Contemporánea, 35, 2007, pp. 491-506.

Montero, José A., «Diplomacia pública, debate político e historiografía en la política exterior de los Estados Unidos (1938-2008)», Ayer, 75, 2009, pp. 63-95.

Moradiellos, Enrique, El reñidero de Europa. Las dimensiones internacionales de la guerra civil española, Península, Barcelona, 2001. 
MORADIELlOS, Enrique, «La intervención extranjera en la guerra civil: un ejercicio de crítica historiográfica», Ayer, 50, 2003, pp. 199-234.

MorAdiEllos, Enrique, «El mundo ante el avispero español: intervención y no intervención extranjera en la guerra civil», in JuLIÁ, Santos (coord.), República y Guerra Civil, Espasa Calpe, Madrid, 2004, pp. 287-362.

MorAdiELlOS, Enrique, «El gobierno británico y la guerra de España: apaciguamiento y no intervención», Historia del Presente, 7, 2006, pp. 71-88.

MoradiEllos, Enrique, Franco frente a Churchill: España y Gran Bretaña en la Segunda Guerra Mundial, Península, Barcelona, 2007.

Mota Zurdo, David, «José Laredogoitia Menchaca, el agente Gernika», Sancho el sabio: revista de cultura e investigación vasca, 37, 2014, pp. 159-179.

Mota Zurdo, David, Un sueño americano. El Gobierno Vasco en el exilio y Estados Unidos (1937-1979), IVAP, Oñati, 2016.

Mota ZuRdo, David, «La fallida operación Airedale. La OSS y el Servicio Vasco de Información contra la Alemania nazi», Revista Historia Autónoma, 10, 2017, pp. 145-162.

NúÑEZ, Xosé M., «¿Protodiplomacia exterior o ilusiones ópticas? El nacionalismo vasco, el contexto internacional y el Congreso de Nacionalidades Europeas», Cuadernos de sección Historia y Geografía, 23, 1995, pp. 243-275.

NúÑEZ, Xosé M., «Relaciones exteriores del nacionalismo vasco». In DE PABLo, Santiago (ed.), Los nacionalistas. Historia del nacionalismo vasco, 18761969, Fundación Sancho el Sabio, Vitoria-Gasteiz, 1995, pp. 381-417.

NúÑEZ, Xosé M., ¡Fuera el invasor! Nacionalismos y movilización bélica durante la guerra civil española (1936-1939), Marcial Pons, Madrid, 2006.

Oiarzabal, Pedro J. and TABernilla, Guillermo, «El enigma del mito y la historia: «Basque code talkers» en la Segunda Guerra Mundial. La OSS y el Servicio Vasco de Información-La Organización Airedale», Saibigain: Revista digital de la Asociación Sancho de Beurko, 3, 2017, pp. 11-156.

ORDAZ, María de los A., «La delegación vasca en Nueva York, una década bajo el punto de mira del FBI (1938-1947)», Estudios de historia social y económica de América, 12, 1995, pp. 179-198.

Payne, Stanley G., Franco y Hitler: España, Alemania, la Segunda Guerra Mundial y el holocausto, La Esfera de los libros, Madrid, 2008.

PizArroso, Alejandro, Diplomáticos, propagandistas y espías, Estados Unidos y España en la Segunda Guerra Mundial: información y propaganda, CSIC, Madrid, 2009.

Portero, Florentino, «El régimen franquista y Estados Unidos. De enemigos a aliados», in Delgado, Lorenzo y Elizalde, María Dolores (coord.), España y Estados Unidos en el siglo XX, CSIC, Madrid, 2005, pp. 41-55.

Redondo, Gonzalo, Historia de la Iglesia en España 1931-1939. Tomo II La Guerra Civil (1936-1939), Rialp, Madrid, 1993. 
Knocking on America's door. Basque Foreign Politics in the US during the Spanish Civil...

REY, Marta, «Fernando de los Ríos y Juan F. Cárdenas: dos embajadores para la guerra de España (1936-1939)», REDEN, 7, 11, 1996, pp. 129-150.

REY Y, Marta, Stars for Spain: la guerra civil española en los Estados Unidos, Ediciones Do Castro A Coruña, 1997.

Ros, Manuel, La Gran Tentación, Franco, el imperio colonial y los planes de intervención en la Segunda Guerra Mundial, Styria, Barcelona, 2008.

Ros, Manuel, Franco/Hitler 1940: de la Gran Tentación al Gran Engaño, Arco, Madrid, 2009.

SAITUA, Iker, Sagebrush Laborers: Basque Immigrants in Nevada's Sheep Industry, Internationl Dimensions, and the Making of an Agricultural Workforce, 1880-1954, University of Nevada, Reno, 2016.

SAITUA, Iker, «The Best Sheepherder. El estereotipo racial de los inmigrantes vascos en el Oeste norteamericano entre finales del siglo XIX y principios del XX», Historia Contemporánea, 56, 2018, pp. 81-119.

San Sebastián, Koldo, The Basque Archives: vascos en Estados Unidos (19381943), Txertoa, San Sebastián, 1991.

Smith, I. C., Inside. A Top G-Man Exposes Spies, Lies, and Bureaucratic Bungling Inside the FBI, Thomas Nelson Press, Nashville, 2009.

Stiglitz, Joseph E., Macroeconomía, Barcelona: Ariel, 2004.

TheOHARIS, Athan G., The FBI: A Comprehensive Reference Guide, The Orix Press, Phoenix, 1999.

Thòmas, Joan M., Roosevelt y Franco. De la guerra civil española a Pearl Harbor, Edhasa, Barcelona, 2007.

TotoriCAgÜEnA, Gloria, The Basques of New York: a Cosmopolitan Experience, Vitoria-Gasteiz, Gobierno Vasco, 2003.

Ugalde, Alexander, La Acción Exterior del Nacionalismo Vasco (18901939): Historia, pensamiento y Relaciones Internacionales, IVAP, Oñati, 1996.

UGALDE, Alexander, «Las relaciones internacionales del nacionalismo vasco (1890-1936) y del primer Gobierno Vasco (1936-1939)», in AldECOA, Francisco y KeAting, Michael (ed.), Paradiplomacia: las relaciones internacionales de las regiones, Marcial Pons, Madrid, 2000, pp. 183-201.

WeINER, Tim. Enemigos, Una Historia del FBI, Debate, Barcelona, 2012.

WIGG, Richard, Churchill y Franco. La política británica de apaciguamiento y la supervivencia del régimen, 1940-1945, Debate, Barcelona, 2005.

Yeadon, Glenn and Hawkins, John, The Nazi Hydra in America: Suppressed History of a Century, Progressive Press, Joshua Tree, 2008.

ZanCA, José A, El humanismo cristiano y la cultura católica argentina (19361959), Universidad de San Andrés, Buenos Aires, 2009. 


\section{Financiación}

Este artículo se ha realizado como parte del proyecto PGC2018094133-B-100 (MCIU/AEI/FEDER, UE) que dirige Coro Rubio Pobes y dentro del Grupo de Investigación GIR 03 Humanidades y Ciencias sociales en la Era digital y Tecnológica de la Universidad Isabel I y de la línea de investigación «L.06. Política, Economía, Sociedad y Memoria: El Estado en los siglos XIX a XXI».

\section{Datos del autor}

Doctor en Historia por la Universidad del País Vasco y profesor del grado de Historia y Geografía en la Universidad Isabel I. Ha sido investigador invitado en el BMW Center for German and European Studies de la Universidad de Georgetown (Estados Unidos) y en el Centro de Estudios sobre Conflictos Sociales de la Universitat Rovira i Virgili. Es autor de Un sueño americano. El Gobierno Vasco en el exilio y Estados Unidos (1937-1979) y Los 40 Radikales. La música contestataria vasca y otras escenas musicales: origen, estabilización y dificultades (1980-2015); y coautor de Testigo de cargo: La historia de ETA y sus víctimas en televisión (2019). Actualmente también dirige el Grupo de Investigación GIR 03 Humanidades y Ciencias sociales en la Era digital y Tecnológica de la Universidad Isabel I donde coordina la línea de investigación «L.06. Política, Economía, Sociedad y Memoria: El Estado en los siglos XIX a XXI». 